See Article page 148.

\section{Commentary: Still searching for the Holy Grail 70 years later: I can see some light}

\author{
Carlos A. Mestres, MD, PhD, FETCS, ${ }^{\mathrm{a}, \mathrm{b}}$ and \\ Zoran Rancic, $\mathrm{MD}, \mathrm{PhD}^{\mathrm{c}}$
}

The search for the Holy Grail in vascular reconstructive surgery is epitomized by 70 years of efforts to find the ideal graft for small arteries, from the coronaries and intracranial to the below-the-knee or pedal. It is an old story and the subject of research by Sauvage 5 decades ago, ${ }^{1}$ who implanted short $(4 \mathrm{~cm})$, small (3.5 inner diameter) Dacron vascular grafts between the ascending aorta and right coronary artery with a successful 15-month follow-up. He stated that success with small arterial grafting depends on low graft implant thrombogenicity and rapid, complete healing of implanted prostheses. ${ }^{1}$ Materials and coatings, such as umbilical cord vessels, ${ }^{2}$ polytetrafluoroethylene, ${ }^{3,4}$ polyethylene, ${ }^{5}$ tanned ovine grafts, ${ }^{6}$ and others, have been tested in animal and humans, with frequently disappointing degrees of success. Small-caliber grafts are $<6 \mathrm{~mm}$; although we have grafts like the internal mammary artery for the myocardium, ${ }^{7}$ we are still searching for the ideal substitute for distal arterial beds when autologous tissue is not available.

Vascular graft tissue engineering has defined and optimized tissue-engineered vascular graft alternatives to replicate native vessels. Tissue-engineered vascular graft focuses on materials, mechanical characteristics, and surface optimization concerning endothelialization and tissue retraction, a complex biological process; interplay between scaffolds and cellular engrafting should determine ideal

From the Departments of ${ }^{\mathrm{a} C}$ Cardiac Surgery, and ${ }^{\mathrm{c}}$ Vascular Surgery, University Hospital Zürich, Zürich, Switzerland; and ${ }^{\mathrm{b}}$ Department of Cardiothoracic Surgery, The University of the Free State, Bloemfontein, South Africa.

Disclosures: Dr Mestres reported receipt of consulting fees from the Edwards Clinical Events Committee and Cytosorbents Corp. Dr Rancic reported no conflicts of interest.

The Journal policy requires editors and reviewers to disclose conflicts of interest and to decline handling or reviewing manuscripts for which they may have a conflict of interest. The editors and reviewers of this article have no conflicts of interest.

Received for publication March 12, 2021; accepted for publication March 16, 2021; available ahead of print April 9, 2021.

Address for reprints: Carlos A. Mestres, MD, PhD, FETCS, Department of Cardiac Surgery, University Hospital Zürich, Rämistrasse 100, CH-8091 Zürich,

Switzerland (E-mail: Carlos.Mestres@usz.ch).

JTCVS Open 2021;6:159-60

2666-2736

Copyright (C) 2021 The Author(s). Published by Elsevier Inc. on behalf of The American Association for Thoracic Surgery. This is an open access article under the CC BY-NC-ND license (http://creativecommons.org/licenses/by-nc-nd/4.0/).

https://doi.org/10.1016/j.xjon.2021.03.008

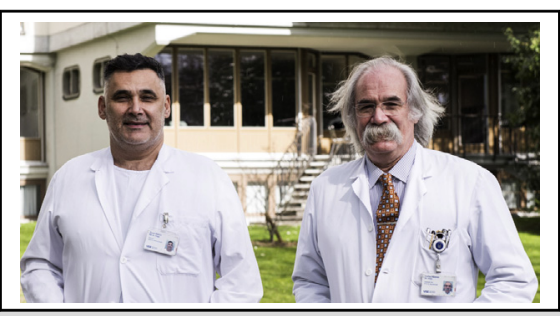

Zoran Rancic, MD, PhD (left), and Carlos A. Mestres, MD, PhD, FETCS (right)

\section{CENTRAL MESSAGE}

There is smooth muscle cell proliferation and rapid growth of extracellular matrix, in line with experiments showing the ability of silk-based small-caliber scaffolds to induce angiogenesis.

graft behavior. ${ }^{8}$ A thick, irregular, unattached neointima of low quality in terms of compliance and flexibility, as well as subintimal fibrosis, seem to be at the root of the problem. ${ }^{9}$

In this issue of the Journal, Tanaka and colleagues ${ }^{10}$ present their experience with small-diameter silk fibroin vascular graft $(3.5 \mathrm{~mm})$ in a dog model. Graft patency in the femoral artery position was $80 \%$, and the lumen was covered with vascular endothelial cells after 3 months. No aneurysms, calcification, granulomas, or infection was seen at 1 year. The authors stress the graft remodeling capability.

This small-diameter vascular graft in a large animal model brings good news. First is the high patency; second, the improved silk fibroin coating rapidly degrades after implantation. The authors describe smooth muscle cells and elastic fiber layers in the lumen and endothelial cells in the innermost surface of the graft after 3 months with no significant histologic narrowing at 1 year. Endothelial cells may prevent stenosis.

The model has some weaknesses, as the authors did not compare their grafts with other grafts and used pharmacologic support to counteract platelet-graft interaction. On the other hand, antiplatelets are widely used in real-world patients with vascular disease requiring open surgery with great saphenous vein or synthetic grafts. ${ }^{11}$

Silk-based small-caliber grafts have long been used in research using small animal models. Silk fibroin seems to enhance the adhesion and proliferation of vascular cells, ${ }^{12}$ as the authors describe. Lack of endothelialization is a major cause of graft and stent failure. Despite some limitations, these experiments confirm smooth muscle cell proliferation 
and rapid growth of extracellular matrix, in line with experiments demonstrating the ability of silk-based small-caliber scaffolds to induce angiogenesis. ${ }^{13}$

Current research pursues the Holy Grail in vascular reconstruction. Experimental vascular grafts have been under investigation and optimization for decades. ${ }^{14}$ Previous findings like those of Sauvage ${ }^{1}$ remain current today. Let us see how silk and modern technology will help us. ${ }^{10,13-15}$

\section{References}

1. Sauvage LR. The future of porous-fabric arterial prostheses. A subject for continued research. Ann Thorac Surg. 1975;19:333-5.

2. Christie BA, Ketharanathan V, Perloff LJ. Minute vascular replacements. Arch Surg. 1982;117:1290-4.

3. Schwann TA, Habib RH, Wallace A, Shahian D, Gaudino M, Kurlansky P, et al. Bilateral internal thoracic artery versus radial artery multi-arterial bypass grafting: a report from the STS database. Eur J Cardiothorac Surg. 2019;56: 926-34.

4. Dardik H, Dardik II. Successful arterial substitution with modified human umbilical vein. Ann Surg. 1976;183:252-8.

5. Weinstein PR, Reinert RL, Brittain F. Delayed thrombosis of synthetic microvascular bypass grafts. Neurosurgery. 1981;9:268-74.

6. Murtra M, Mestres CA, Igual A. Long-term patency of polytetrafluoroethylene vascular grafts in coronary artery surgery. Ann Thorac Surg. 1985:39:86-7.
7. Hamann H. [Replacement of small caliber arteries with synthetic transplants.] Fortschr Med. 1981;99:1457-62 [in German].

8. Leal BBJ, Wakabayashi N, Oyama K, Kamiya H, Braghirolli DI, Pranke P. Vascular tissue engineering: polymers and methodologies for small caliber vascular grafts. Front Cardiovasc Med. 2021;7:592361.

9. Hess F, Jerusalem C, Grande P, Braun B. Significance of the inner-surface structure of small-caliber prosthetic blood vessels in relation to the development, presence, and fate of a neo-intima. A morphological evaluation. J Biomed Mater Res. 1984;18:745-55.

10. Tanaka T, Tanaka R, Ogawa Y, Takagi Y, Sata M, Asakura T. Evaluation of smalldiameter silk vascular grafts implanted in dogs. J Thorac Cardiovasc Surg Open. 2021;6:148-56.

11. Conte MS, Bradbury AW, Kohl P, White JV, Dick F, Fitridge R, et al. Global vascular guidelines on the management of chronic limb-threatening ischemia. Eur J Vasc Endovasc Surg. 2019;69:3S-125S.e40.

12. Sun XL, Hao YX, Wang QY, Dong FL, Wang JN. Cell growth and proliferation on the interface of a silk fabric tubular scaffold. Text Res J. 2016;86:2193-201.

13. Li H, Song G, Tian W, Ding M, Sun X, Xu J, et al. Motility and function of smooth muscle cells in a silk small-caliber tubular scaffold after replacement of rabbit common carotid artery. Mater Sci Eng C Mater Biol Appl. 2020;114:110977.

14. Sauvage LR, Harkins HN. Experimental vascular grafts: an evaluation relating to types, means of preservation, and methods of suture in the growing pig. Surgery. 1953;33:587-635.

15. Iglesias-Echevarria M, Durante L, Johnson R, Rafuse M, Ding Y, Bonani W, et al. Coaxial PCL/PEG-thiol-ene microfiber with tunable physico-chemical properties for regenerative scaffolds. Biomater Sci. 2019;7:3640-51. 